\title{
El psicobolche: juventud, cultura y política en la Argentina de la década de 1980
}

\author{
The psychobolche: youth, culture and politics in the \\ Argentina of the 1980s
}

Valeria Manzano*

\begin{abstract}
Resumen: Este artículo reconstruye la historia política y cultural de la figura satírica del "psicobolche" en la Argentina de la década de 1980. A partir de esta figura, el artículo analiza las transformaciones en las relaciones entre juventud, política y cultura de izquierdas en el contexto de la "transición democrática", cuando un imaginario en torno a la revolución convivió en tensión con un lenguaje centrado en la democracia y sus virtudes. Esas tensiones estallaron en el último tercio de la década, y la satirización de la figura del psicobolche constituyó una vía por la cual diversas cohortes juveniles debatieron públicamente sobre la "crisis de la izquierda" y aquello que ya se comenzaba a denominar como postmodernismo.
\end{abstract}

Palabras clave: Argentina, juventud, historia reciente, historia de la izquierda, transición democrática.

Abstract: This article reconstructs the political and cultural history of a satirical figure, the "psicobolche", as it appeared in 1980s Argentina. Through this figure, the article analyzes the transformations in the relationships among youth, politics, and leftwing culture in the so-called "democratic transition", when an imaginary centered on ideas of revolution problematically coexisted with a language focused on democracy and its virtues. Those tensions erupted in the last third of the decade, and the satirical construction of the "psicobolche" served as a venue for different youth cohorts to publicly discuss on the "crisis of the left" and what was beginning to be known as postmodernism.

Key words: Argentina, Youth, Recent History, Democratic Transitions.

Recibido: 23 octubre 2017

Aceptado: 26 diciembre 2017

\footnotetext{
* Argentina, historiadora, investigadora de CONICET y profesora del Instituto de Altos Estudios Sociales de la Universidad de San Martín: amanzano@umail.iu.edu Versiones anteriores de este trabajo se presentaron en el Núcleo de Historia Reciente de IDAES, en las XVI Jornadas Inter-Escuelas de Historia y en el Grupo de Estudios de Política y Juventudes de la UBA. Agradezco los comentarios y sugerencias de los colegas asistentes a esos eventos y también los de Mauro Pasqualini y Pablo Alabarces.
} 
En abril de 1987, el por entonces muy joven periodista Marcelo Figueras contaba la ficcional historia de un académico sueco que recopilaba términos en peligro de extinción: uno de ellos, que se había difuminado en Buenos Aires y "las capitales de las provincias interiores", era el de "psicobolche". Dícese, sugería el académico sueco, "del individuo que reclama para sí la pertenencia al izquierdismo" pero, aclaraba, "no todos los izquierdistas son psicobolches". ¿Qué más hacía falta? En primer lugar, una gama de prácticas y consumos culturales entre los cuales destacaban, en principio, la utilización de cierta jerga psicoanalítica (como lo indicaría el "psico") y también el privilegio de ciertos gustos musicales: “¿escuchaste el último de Silvio?”, preguntaría el psicobolche, mientras "sentiría culpa si se encuentra tarareando un tema de Prince". En segundo lugar, hacía falta una modalidad de vinculación con la política donde predominaban ciertos slogans antiimperialistas pero, según el académico sueco, poca indagación más profunda ya que "el psicobolche no se preocupa por preguntarse qué quiere decir ser de izquierda a un paso de los noventa: alcanza con parecerlo". ${ }^{1}$ De acuerdo a Figueras, el término y la figura que evocaba ya estaban en franca retirada. Ambos, de todas formas, eran indicativos de un tipo de relaciones entre juventud, cultura y política que habría tenido su apogeo en los dos primeros tercios de la década de 1980.

Desde las perspectivas de la historia cultural y política, este ensayo reconstruye los recorridos de la figura satírica del psicobolche en la Argentina de la década de 1980. Aunque posiblemente circulara oralmente antes, el término apareció por primera vez en el registro escrito en 1985 en revistas clave de la renovación periodística de los años ochenta, como El porteño, Cerdos \& Peces, y El Periodista de Buenos Aires, o más consagradas, como Humor. Lo introdujo una cohorte de periodistas jóvenes, suponiendo que se trataba de un término que no requería explicaciones, hasta que comenzaron a deconstruirlo, de modo más mordaz, recién desde $1987 .^{2}$ La naturalidad con la cual el término se introdujo por escrito quizá tenga que ver con el lector que esos periodistas imaginaban. Uno de los pocos estudios sobre perfiles culturales y políticos de los estudiantes de la Universidad de Buenos Aires (UBA) indicaba que, en 1985, 22 porciento de los encuestados elegían esas revistas. ${ }^{3}$ Era en el encuentro entre esa cohorte de periodistas y los lectores universitarios donde se producía un "nosotros" en el cual la figura del psicobolche producía sus sentidos satíricos. Reconocidamente la forma más agresiva de lo cómico, la sátira funciona en tanto “ironía militante"- tal como la definió Northop Frye. ${ }^{4}$ Quienes incorporaron por escrito el término psicobolche, como muchos que lo utilizaron de modo oral, ponían en el centro de la discusión los límites de los sectores medios juveniles al involucrarse en proyectos politicos y culturales de izquierda. Según Frye, la sátira es efectiva cuando el satírico y su público comparten el objeto: en el caso del psicobolche se trataba de un "nosotros" definido en términos generacionales y socioculturales.

\footnotetext{
${ }^{1}$ Marcelo Figueras, "La decadencia del imperio psicobolche”, Humor No. 195, abril de 1987, 70-72.

${ }^{2}$ Es muy poco lo que se ha escrito sobre esas revistas de la década de 1980, remito para datos básicos a Carlos Ulanovsky, Paren las rotativas, vol. 2, Emecé, 2005; Mara Burkart, De Satiricón a HUMOR: risa, cultura y políitca en los setenta, Buenos Aires, Miño y Dávila, 2016.

${ }^{3}$ Mario Toer, Cómo son los estudiantes, Buenos Aires, Catálogos, 1990, 76.

${ }^{4}$ Northop Frye, Anatomy of Criticism: Four Essays, Hardomsworth, Penguin, 1990, 233.
} 
En este trabajo - que forma parte de un proyecto más abarcador sobre la historia política, cultural y sexual de los y las jóvenes en la Argentina de la década de 1980 - he elegido reconstruir la figura del psicobolche en un intento por colaborar a la expansión de nuestro conocimiento en dos campos de la historia reciente. ${ }^{5}$ En primer lugar, este artículo se inserta dentro del emergente campo de historia de las juventudes que en la Argentina, y en el Cono Sur, se ha concentrado en las décadas de 1960 y 1970, y en particular en el estudio de movimientos contraculturales y de la participación juvenil-y básicamente estudiantil —en diversos proyectos radicalizados. ${ }^{6}$ Mucho menos abundante es la literatura dedicada a los discursos sobre la juventud y a las experiencias juveniles durante la última dictadura (1976-1983) y en contextos de transición. Parte de lo conocido se produjo desde la sociología de la cultura, los estudios de comunicación y la historia del arte y se ha enfocado en la participación juvenil en "culturas de resistencia", en especial ligadas al rock y a las experiencias underground en las artes expresivas. ${ }^{7}$ Esta literatura ha propuesto líneas de continuidad entre el momento dictatorial y la post-dictadura en lo referente a la apertura de los sentidos de lo político, más ligados a las transformaciones subjetivas que a la participación en proyectos colectivos y programáticos tendientes al cambio social. Seguiré algunas de esas pistas, aunque resaltaré algunas diferencias. Por un lado, a partir de la figura del psicobolche - y de su discusión pública — es posible detectar antes bien rupturas entre el momento transicional y el anterior. Por otro lado, la mera existencia pública de la figura del psicobolche indica que aquellas "políticas de la subjetividad" coexistieron con la experiencia de re-politización juvenil en la vida de los partidos y del movimiento estudiantil. ${ }^{8}$ De hecho, buena parte de los efectos satíricos de la figura del psicobolche fueron los generados por oposición a esos otros segmentos juveniles, identificados como "los modernos"-y luego, postmodernos.

Asimismo, desde la historia de la juventud - y de una figura dentro de la mismaeste ensayo colabora con la expansión de otro campo de indagaciones: el estudio histórico

\footnotetext{
${ }^{5}$ El proyecto de investigación se titula "Una historia de la juventud en la Argentina: cultura, política y sexualidad, 1974-1989", y está acreditado por el Consejo Nacional de Investigaciones Científicas y Técnicas. Asimismo, el propio forma parte de un proyecto de colaboración, que actualmente coordino: "Juventud, cultura y política en la historia reciente: entre lo local, lo nacional y lo transnacional", Proyecto de Investigación Científica y Tecnológica (PICT), 2015-3578, Ministerio de Ciencia y Tecnología.

${ }^{6}$ Vania Markarian, El '68 uruguayo: entre cócteles molotov y música beat, Bernal, Universidad Nacional de Quilmes, 2012; Valeria Manzano, The Age of Youth in Argentina: Culture, Politics, and Sexuality from Perón to Videla, Chapel Hill, University of North Carolina Press, 2014; Patrick Barr-Melej, Psychedelic Chile, Chapel Hill, University of North Carolina Press, 2017.

${ }^{7}$ Pablo Vila, "Rock nacional: crónicas de la resistencia juvenil", en Elizabeth Jelin, ed. Los nuevos movimientos sociales/1, Buenos Aires, Centro Editor de América Latina, 1985; Viviana Usubiaga, Imágenes inestables: Artes visuales, dictadura y democracia en Buenos Aires, Buenos Aires, Edhasa, 2012; Irina Garbatzky, Los ochenta recienvivos: poesía y performance en el Río de la Plata, Rosario, Beatriz Viterbo, 2013; Valeria Garrote, "La estrategia de la alegría en los colectivos artísticos de la dictadura y la postdictadura, España y Argentina (1973-1989)", Tesis doctoral inédita, Rutgers University, 2013; Daniela Lucena y Gisela Laboureau (eds.), Modo mata moda: Arte, cuerpo y (micro) política en los 80, La Plata, EDULP, 2016.

${ }^{8}$ Ver especialmente Rafael Blanco y Pablo Vommaro, "Otros caminos, otros destinos: transformaciones en los espacios y prácticas cotidianas de participación juvenil en los años ochenta”, en Melina Vázquez, Pablo Vommaro, Pedro Nuñez y Rafael Blanco (comps), Militancias juveniles en la Argentina democrática, Buenos Aires, Imago Mundi, 2017, 1-25.
} 
de la década de 1980. Con su foco en un segmento sociocultural y político especifico, este trabajo propone una cronología que se inicia en 1981-y coincide, en ello, con quienes revisan el primer contexto de apertura asociado a la presidencia del General Roberto Viola ${ }^{9}$ - y se cierra hacia 1986: ésos fueron los "ochenta del psicobolche", expresivos de un tipo de vínculo entre política, cultura y juventud. Quienes se politizaban en ese contexto transicional también rendían cuentas con generaciones pasadas (muy notablemente, con la de la década del setenta). En tal sentido, la figura del psicobolche permite una entrada para complejizar nuestro conocimiento sobre la convergencia en el tiempo de un imaginario asociado a la revolución y otro donde se enfatizaban las virtudes de los ideales democráticos. Esas convergencias (y tensiones) no eran privativas del escenario local sino que atravesaban los debates de las izquierdas a escala transnacional en la década de $1980 .^{10}$ Lo específico de la Argentina es que esos debates se dieron en una dinámica política de la cual participaron, con diferentes modalidades, diversas cohortes etarias, algunas con tradiciones e involucramiento previo en proyectos radicalizados y otras-las estudiadas aquí-con menor o nula participación. ${ }^{11}$ La figura del psicobolche y su deconstrucción mordaz en el último tercio de la década de 1980 son parte de la historia de la izquierda, desplegada en las intersecciones de la política y las prácticas culturales.

Además de hacer un uso extensivo de las revistas de la renovación periodística de los ochenta, este ensayo utiliza prensa periódica de circulación masiva - como los diarios Clarín y Tiempo Argentino-y también prensa política. El primer segmento hace un uso indicial de la figura del psicobolche a partir de la reconstrucción de las variaciones en las pautas de consumo de ciertos productos culturales, notablemente los ligados a la música. Sugiero que desde 1981 hasta, al menos, 1985, las transformaciones en la cultura del rock y su imbricación con otras declinaciones de la música popular constituyeron un espacio sónico, cultural y político donde se produjo y adquirió sentidos la figura del psicobolche. El segundo segmento explora las transformaciones de la cultura política juvenil en el contexto transicional. El segmento se enfoca en el Movimiento de las Juventudes Políticas (MOJUPO), lanzado en mayo de 1983 e integrado por las ramas juveniles de la Unión Cívica Radical, el Partido Justicialista, el Partido Intransigente, el Partido Comunista y varias fracciones del socialismo. Continuando con cierta vitalidad hasta 1986, el MOJUPO representó un intento de confluencia entre esas ramas juveniles y, aún más significativo desde la perspectiva de este ensayo, una apuesta por configurar tradiciones y memorias para una cohorte que ingresaba a la militancia. ${ }^{12}$ Como lo retomaría satíricamente el periodista Jorge Dorio, fue en ese contexto en el cual surgieron ciertos slogans que, a su criterio, marcaban el "ADN psicobolche", incluyendo el famoso cantito de esas juventudes:

\footnotetext{
${ }^{9}$ Ver especialmente Paula Canelo, El proceso en su laberinto: la interna militar de Videla a Bignone, Buenos Aires, Prometeo, 2008.

${ }^{10}$ Ver Geoff Eley, Forging Democracy: the History of the Left in Europe, 1850-2000, New York, Oxford University Press, 2002, 405-427.

${ }^{11}$ Para una interpretación de los procesos de "des-radicalización" y giro hacia el lenguaje democrático entre militantes de la década de 1970, María Matilde Ollier, De la revolución a la democracia, Buenos Aires, Siglo XXI, 2009.

${ }^{12}$ Para una historización del MOJUPO, ver también Marina Larrondo y Alejandro Cozachcow, "Un llamado a la unidad: la experiencia del Movimiento de Juventudes Políticas (MOJUPO) en la transición a la democracia", en Vázquez et al, Militancias juveniles, 51-71.
} 
"radicales de Yrigoyen / peronistas de Perón / comunistas e intransigentes / para la liberación". ${ }^{13}$ El tercer segmento retoma las intervenciones periodísticas que, desde 1987 en adelante, se enfocaron en el modelado más más sarcástico de la figura del psicobolche. Esas intervenciones propusieron también una crítica a las relaciones entre política, cultura y juventud tal como - aseguraban — se había gestado a comienzos de la década de 1980 e inauguraron una reflexión en torno a la así denominada "crisis de la izquierda" vis-a-vis la emergencia de cierta apatía y desilusión que pronto tomó el nombre de "postmodernismo".

\section{"En el reino del psicobolche onda PI..."}

En 1985, en una crónica de la noche de Buenos Aires, el periodista y organizador contracultural Enrique Symns contraponía una (por cierto, mítica) noche de la década de 1960, a la que describía como agitada y "poblada de verdaderos personajes marginales", con la "frívola y/o aburrida" noche de la década de 1980. Con la mediación de la dictadura y sus estrategias represivas, de acuerdo a Symns, la noche porteña había decantado en dos circuitos: uno era "el de las discos frívolas" y, el otro, el del "aburrimiento" de la Avenida Corrientes, en cuyos bares "jovencitos con Freud bajo el brazo" prolongaban sus charlas tras funciones teatrales o recitales. Allí se instalaba "el reino del psicobolche onda PI". ${ }^{14}$ En una de sus primeras apariciones por escrito, el término psicobolche se asociaba con consumos culturales (lo "psi" junto al teatro y los recitales) e inclinaciones políticas que, en la síntesis de Symns, se resumían en el Partido Intransigente (PI). Para 1985, esas referencias bastaban para que los lectores de El porteño se hicieran una idea de qué se estaba hablando: el psicobolche ya era una figura conocida. Mientras que el consumo de terapias y la utilización de una jerga "psi" era común entre los sectores medios intelecualizados desde los años sesenta, dos décadas después esa tendencia se reforzó. La vinculación de jóvenes con intereses por la política - en especial, de izquierda - con el discurso y la práctica "psi" se combinó con el modelamiento de consumos culturales entre los que destacaban ciertos gustos musicales que entremezclaban vertientes del rock con la "proyección folklórica". A partir de esos consumos-y de sus vinculaciones con la política - se delinearon, también, distinciones intra-generacionales.

El "psico" antepuesto al "bolche" en la construcción de esa figura enfatizaba los usos de terapias y jerga "psi” en un segmento juvenil con intereses políticos. Como lo ha mostrado Mariano Plotkin, en la década de 1960 la cultura "psi” adquirió una pregnancia significativa entre los sectores medios urbanos, para quienes el psicoanálisis devino una clave interpretativa para navegar procesos de modernización sociocultural. ${ }^{15} \mathrm{Al}$ despuntar la década de 1970, en plenas dinámicas de politización y radicalización, revistas como la cordobesa Hortensia y las porteñas Satiricón y Chaupinela, sin avanzar en un apelativo, dedicaron parte de sus iniciativas a conquistar y satirizar a las juventudes politizadas, incluyendo los modos en que usaban giros del lenguaje psicoanalítico. "Complejo", "culpa"

\footnotetext{
13 Jorge Dorio, "La insoportable levedad del psicobolche”, El porteño no. 77, mayo de 1988.

${ }^{14}$ Enrique Symns, "Largo viaje al fin de la noche”, El porteño no. 46, octubre de 1985, 20-4.

15 Mariano Plotkin, Freud en las Pampas: Orígenes y desarrollo de una cultura psicoanalítica en la Argentina (1910-1983), Buenos Aires, Sudamericana, 2003.
} 
o "neura" eran parte de un bagaje conceptual que, de acuerdo a humoristas gráficos y periodísticos, rápidamente devinieron clichés. ${ }^{16} \mathrm{La}$ imbricación entre militancia juvenil, especialmente de izquierda, y cultura "psi" no era una novedad en los ochenta. Posiblemente sí era novedosa la extensión del cuerpo de estudiantes de Psicología y también la utilización de psicoterapias entre los estudiantes universitarios en general. De acuerdo al censo de alumnos de la Universidad de Buenos Aires, en 1988 la carrera de Psicología ocupaba el cuarto lugar (detrás de Ciencias Económicas, Derecho y Medicina) en función a la cantidad de estudiantes matriculados: eran 10.300 varones y mujeres que representaban un 9 porciento del total de la UBA. Esas cifras contrastaban con las del censo de alumnos de 1968, cuando la carrera tenía 2800 estudiantes, que representaban el 4 porciento del total de la UBA. ${ }^{17}$ El crecimiento de la matrícula en Psicología se dio en un contexto en el que la población estudiantil de la UBA en su conjunto participaba del mundo "psi". En 1986, una encuesta que buscaba trazar perfiles socioculturales preguntó a los estudiantes de todas las carreras si hacían algún tipo de psicoterapia: 24 porciento contestó afirmativamente (entre los estudiantes de Psicología, ascendía al 68 porciento). ${ }^{18}$ Para mediados de los años ochenta, así, había un segmento importante de estudiantes involucrado con las psicoterapias y su jerga. De acuerdo a las representaciones satíricas, allí se encontraba uno de los núcleos duros de quienes formaban el contingente de psicobolches aunque, como se mofaba Jorge Dorio, "no es necesario que el psicobolche tenga relación directa con el psicoanálisis" ya que "bastará una amiga psicóloga que facilite giros convenientes, después empezará a llamar "compañera" a su novia, leerá El Porteño o Humor, y silbará temas de Silvio o de la Negra."19 Era desde ese consumo cultural, y especialmente musical, que el psicobolche se tornaba una figura reconocible.

La historización de las relaciones entre jóvenes y consumos musicales en la Argentina se han enfocado, no si razón, en el universo del rock, señalando cómo desde mediados de la década de 1960, los roqueros — músicos, poetas, fans - fueron dando forma a una cultura que se pretendía alternativa al "sistema", antiautoritaria y, en alguna medida, horizontalista. Desde la última dictadura militar, las relaciones entre las nuevas autoridades y el mundo roquero atravesaron, al menos, tres grandes momentos. El primer período, entre 1976 y 1978, fue de relativa tolerancia: se permitía la realización de grandes conciertos y hasta los medios más regiminosos reporteaban a los principales referentes, como Luis Alberto Spinetta, a quienes se presentaba como abocados al mundo de la creación y la cultura antes que a la política. Esa tendencia fue cambiando hacia 1978, iniciándose el segundo de los períodos, marcado por la persecución de muchos músicos y las crecientes dificultades para la organización de recitales. Fue en ese bienio cuando, al decir del sociólogo Pablo Vila, el movimiento roquero "hibernó" en pequeños círculos, mucho más íntimos, pero, en el contexto represivo, cimentadores de una "cultura de la resistencia" de tintes antiautoritarios - algo que también tuvo su eco en la diseminación de revistas como

\footnotetext{
${ }^{16}$ Lo he analizado en “'Contra toda forma de opresión': sexo, política y clases medias juveniles en las publicaciones de humor de los tempranos setenta", Sociohistórica, vol. 29, noviembre de 2011.

${ }^{17}$ Universidad de Buenos Aires, Censo general de alumnos 1968, Buenos Aires, 1970, 2, 118; Universidad de Buenos Aires, Censo general de alumnos 1988, Buenos Aires, 1991, cuadro 10.

18 Toer, Cómo son los estudiantes, 34-5.

${ }^{19}$ Dorio, "La insoportable levedad del psicobolche", El porteño no. 77, mayo de 1988.
} 
la legendaria Expreso Imaginario, cuyo correo de lectores sirvió para trazar lazos interjuveniles. Para 1980, sin embargo, se relanzaron las condiciones para la masividad, iniciándose la "era Estadio Obras" de la cultura roquera con las reuniones de bandas ya míticas, como Manal y Almendra, y los recitales de la banda del momento, Serú Giran. ${ }^{20}$

La pregnancia del rock como movimiento musical y cultural juvenil fue una dinámica crucial, y en una de sus declinaciones se nutría de un diálogo poroso con otras vertientes de la música popular. Fue en ese espacio sónico, cultural y político donde gravitó la figura del psicobolche. Ese espacio se delineó hacia 1981, en un contexto de relativa apertura en el cual el campo cultural iniciaba un proceso de intensa politización, marcado por la crítica anti-dictatorial-incluyendo el cuestionamiento de la censura y el reclamo de verdad por las desapariciones de personas. ${ }^{21}$ En lo referente a aquel espacio sónico, una de sus primeras instancias formativas fue el Encuentro de Música Popular Argentina, organizado por Humor y el pub La Trastienda, realizado en el Estadio Obras en agosto de 1981 - en explicita contraposición con la visita de Frank Sinatra al país. Además de la presencia de tangueros, el Encuentro convocó a artistas de proyección folklórica-como Antonio Tarragó Ros, Víctor Heredia, Zupay, "Cuchi” Legizamón, Markama-y a músicos y bandas roqueras, en muchos casos consagrados (Spinetta, Litto Nebbia, Miguel Cantilo y Jorge Durietz, Manal) y en otras recién llegados (Juan Carlos Baglietto y Fito Páez, por ejemplo). En su crónica, el ya por entonces veterano periodista de rock Miguel Grinberg planteaba que mientras los roqueros estaban sumidos en "el formalismo y el tecnicismo"se trataba de una crítica muy frecuente-la "nueva música folklórica" era la que había brillado por su dinamismo. ${ }^{22}$ En eso, al menos, coincidían Grinberg y el crítico de la revista de la Federación Juvenil Comunista (FJC), quien opinaba que el público "de entre 15 y 30 años, con necesidad de sentirse expresado y de expresarse" ovacionó a aquellos artistas que, además de "calidad musical", ofrecieron "sutiles referencias a nuestra realidad. ${ }^{23} \mathrm{El}$ Encuentro de Música Popular tendió puentes entre una revista, segmentos juveniles que se estaban acercando a la política partidaria y un conjunto de artistas de diversas vertientes, con una punta en el rock. A diferencia de lo sucedido con parte de la izquierda a comienzos de la década de 1970, ahora tanto la FJC como la Juventud del PI reconocían la importancia del fenómeno roquero pero - como ya era una tradición desde las izquierdas argentinasreclamaban a los músicos, poetas y fans que "clarificaran sus ideas". ${ }^{24}$ Esos actores

\footnotetext{
${ }^{20}$ Para todo lo antedicho, ver Vila, "Rock nacional"; Manzano, The Age of Youth, cap. 8; Julián Delgado, "No se banca más: Serú Girán y las transformaciones musicales del rock en la Argentina dictatorial," Revista Afuera: Estudios de Crítica Cultural, no. 15, 2015.

${ }^{21}$ En 1981 se lanzó la experiencia de Teatro Abierto, que tuvo ecos en ciclos de "danza abierta" y de "música abierta", y también en la organización de cineastas contra la censura. Una visión panorámica de esas experiencias en Beatriz Trastoy, "Teatro Abierto 1981: un fenómeno social y cultural”, en Osvaldo Pelletieri (ed.), Historia del teatro argentino, 1976-1996, Buenos Aires, UBA/Galerna, 2000.

22 Miguel Grinberg, "Encuentro que me hiciste bien”, Humor no. 65, septiembre de 1981, 90-93; para criticas similares al formalismo y tecnicismo roquero hechas por un músico, ver Claudio Gabis, "Carta a los músicos de los ochenta", Mutantia no. 2, agosto-septiembre de 1980, 14-16.

23 "La música argentina no murió", Aquí y ahora la juventud, no. 12, 13 de agosto de 1981; Miguel Angel Merellano, "El publico en Obras", Humor no. 65, septiembre de 1981, 92.

${ }^{24}$ Ver, entre otras, "La reina de las visitas", Aquí y ahora la juventud, no. 3, 2 de abril de 1981; "Hacia una cultura nacional", Luchar (Juventud Intransigente), no. 1, septiembre de 1982, 9-10.
} 
bregaron por ampliar el espacio sónico, político y cultural, en un esfuerzo porque incluyera, pero no se limitara, al rock.

Otras instancias dieron cuenta de los modos en que ese espacio sónico, político y cultural se perfilaba como uno de encuentros-entre corrientes musicales, entre generaciones, entre segmentos juveniles con diferentes estéticas - y también uno en el que se delineaba un por entonces nuevo lenguaje de la convivencia. En febrero de 1982 volvió al país Mercedes Sosa luego de tres años de exilio y ofreció 13 recitales en el Teatro Opera. Como lo relataba la prensa diaria, el público atravesaba "clases sociales y edades": eran "matrimonios ya en los cincuenta con adolescentes en jeans". ${ }^{25} \mathrm{Y}$ si el encuentro intergeneracional e inter-estético se produjo debajo del escenario, también tuvo lugar arriba: entre los invitados estaban León Gieco y Charly García. Como comentaba Mercedes Sosa a la prensa juvenil comunista, esas invitaciones no sólo tenían que ver con la renovación de su repertorio-donde también incluía a la Nueva Trova cubana y música popular brasileña - sino más fundamentalmente con el hecho que "pude cantar tantas veces con ellos la palabra libertad". ${ }^{26}$ Los roqueros aportaban a ese espacio de convergencia un ideologema clave de su cultura, "la libertad", que se re-semantizaba con declinaciones más coyunturales en un contexto dictatorial. Como parte del mismo movimiento, entraban de lleno al espacio de la música popular de la mano de quien, desde los años sesenta, se había erigido como un baluarte de la canción de proyección folklórica con clara inspiración política. En tal sentido, Gloria Guerrero, quien desde 1981 estaba a cargo de las "páginas" sobre música rock de Humor, reconocía que "ninguno de mi generación sabría decir porqué Mercedes Sosa nos derrite como manteca al sol" y pedía "por favor, ahora que la encontré, no me la saquen". ${ }^{27}$ Guerrero, ufanándose eventualmente de su apoliticismo, admitía sin embargo que ese encuentro había sido transformador. Y, de hecho, esa serie de recitales de Mercedes Sosa era indicativa de un tipo de "encuentro" en el cual diversos segmentos juveniles participaban. Tal lo sucedido, por ejemplo, durante la gira que León Gieco emprendió desde Usuahia a La Quiaca, en la cual-según él mismo contaba — sus estadías habían sido gestionadas por grupos de estudiantes secundarios y universitarios que - a su criterio_-buscaban "tanto rock como música popular", algo que él buscaba producir. ${ }^{28} \mathrm{En}$ la Argentina de comienzos de los ochenta, ese deseo evocaba una voluntad de construcción de un espacio de convergencia, cincelado en la música, que fuera inclusivo: mientras folkloristas como César Isella y Suna Rocha se emocionaban al encontrarse "con adolescentes" en sus recitales, roqueros como Litto Nebbia, o Baglietto y Fito Páez, hablaban de "pluralismo y convivencia" en la música popular. ${ }^{29}$ Esas nociones de convivencia e inclusión estaban a tono con ideales democratizadores y de armonía que recorrían otras avenidas de la cultura y la política.

\footnotetext{
25 "Mercedes Sosa canta con todos", Clarín, 17 de febrero de 1982, 39.

26 "Mercedes y una hermosa prueba de amor", Aquí y ahora la juventud, no. 26, 15 de marzo de 1982.

27 "Regreso con Gloria", Humor no. 77, marzo de 1982, 63.

${ }^{28}$ Mona Moncalvillo, "León Gieco, el Dylan del subdesarrollo", Humor no. 79, abril de 1982, 78-80; "León Gieco y la cultura en tiempos de cambio", El Porteño no. No. 7, julio de 1982, 6-10.

29 "Rock nacional: el desafío de crecer", Clarín Revista, 20 de junio de 1982, 4-5; "La política, el rock, el folklore”, Tiempo Argentino, segunda sección, 29 de diciembre de 1982, 8-9.
} 
El afán de configurar convergencias irradió luego en una serie de recitales que, desde 1983 hasta 1985, facilitó la diseminación de la figura del psicobolche. Cuando ya se habían anunciado las elecciones para octubre de 1983, las crónicas periodísticas abundaban en las entonaciones de "se va a acabar la dictadura militar" en casi todos los recitales roqueros, incluido el Festival de La Falda de 1983 al cual habrían asistido unas 40.000 personas y donde tocaron desde Miguel Abuelo y Pappo hasta Antonio Tarragó Ros y Gieco - la dupla que por entonces mejor sintetizaba al espacio sónico de convergencia. ${ }^{30}$ Sin embargo, el momentum de ese 1983 fueron los recitales que Joan Manuel Serrat dio en el Gran Rex y en el Luna Park en junio, tras ocho años de no tocar en el país. Apenas puestas en venta las entradas, al decir de una crónica, se arremolinaron en la puerta del Luna Park unos "5000 jóvenes". Una estudiante de Psicología- “con pullover con llamas y botas de gamuza"- había pasado toda la noche en guardia, y recordaba que durante los años anteriores, los casetes de Serrat habían circulado sigilosamente entre sus amigos de la facultad. ${ }^{31}$ El día del primer recital, una crónica de la larguísima cola enfatizaba que se cantaba "se va a acabar la dictadura militar", mientras que se repartían volantes de "ayuda psicológica a precios módicos" tanto como volantes de las juventudes de la FJC y el PI. ${ }^{32}$ Casi un año después, cuando ya no era necesario el "se va a acabar", las banderas de esos mismos partidos flameaban en Obras durante la serie de 10 recitales que ofrecieron Silvio Rodríguez y Pablo Milanés, a los cuales asistieron alrededor de 80.000 personas. ${ }^{33} \mathrm{La}$ producción musical de esos representantes de la Nueva Trova cubana se conocía desde hacía poco tiempo en la Argentina, y era facilitada por la inclusión de algunas de sus canciones en los repertorios de otros artistas - como Mercedes Sosa-y de casetes mal grabados que, como había sucedido con Serrat, no paraban de circular de mano en mano (al menos entre los jóvenes más politizados). ${ }^{34}$ Aunque renegaran de ello en la conferencia de prensa que dieron al llegar a Buenos Aires, es posible que su público estuviera compuesto por estudiantes, especialmente universitarios, y con sensibilidad de izquierda. ${ }^{35}$ Los exponentes de la Nueva Trova traían reminiscencias de procesos revolucionarios y la oportunidad de cantar su solidaridad con Cuba, Nicaragua y Chile. Ese renovado latinoamericanismo - como se detalla más abajo - era común a las ramas juveniles de los partidos que en 1983 habían creado el MOJUPO y formó parte de una estética que también irradió en otros consumos, que iban desde viajes de mochileros hasta la vestimenta-la alusión del "pullover con llamas" de la estudiante de Psicología en la cola de Serrat permite configurar el cuadro que pronto se parodiaría con la figura del psicobolche.

Desde 1981 hasta, al menos 1985, así, se fue consolidando un espacio sónico, político y cultural de convergencia entre elementos del rock y de la música “de proyección

\footnotetext{
${ }^{30}$ Roque de Pedro, "Rock y música andina en La Falda", Clarín, 31 de enero de 1983, 25; "La sierra, con eco juvenil", Clarín, 8 de febrero de 1983, 38.

31 "Larga cola para Serrat", Clarín, 3 de mayo de 1983, 28.

32 "Los de afuera y los 3308", Clarín, 3 de junio de 1983, 25; Sibila Camps, "Un volcán llamado Serrat", Clarín espectáculos, 4 de junio de 1983, 2.

${ }^{33}$ Sibila Camps, "El canto, la poesía, el espectáculo", Clarín espectáculos, 5 de abril de 1984, 2; "Por amor a la humanidad", " Clarín espectáculos, 7 de abril de 1984, 2-3.

34 "No envejecer mientras se cante", Aquí y ahora la juventud no. 14, 20 de abril de 1983, 10-11; "Canto popular", Luchar no. 5, septiembre de 1983.

35 Alejandro Tarruela, "Silvio y Pablo, Daniel y Mario", Humor no. 126, abril de 1984.
} 
folklórica", y de ambos con trovadores visitantes. En términos musicales, el privilegio estaba dado por los sonidos acústicos y por la importancia asignada a las letras y sus posibles conexiones con la narración de luchas y sujetos del mundo popular, pero también con modos de vivir el amor y las relaciones de pareja donde destacaran ideas de igualdad, solidaridad y ternura. Si bien este espacio estaba atravesado por ideas convergencia e inclusión, hubo al menos dos figuras (o ramificaciones de una misma) que funcionaron por oposición a la del psicobolche. En primer lugar, una de las segmentaciones de las estéticas y gustos juveniles contrapuestas al psicobolche era la de los "disco", que disfrutaban de salir a bailar, y se preocupaban por la moda y el cuerpo. Esa figura tenía su antecedente en el "cheto" o "careta", epitomizado en el Tony Manero interpretado por John Travolta en Fiebre de sábado a la noche (estrenada en 1977) y encarnado a escala doméstica en la fugaz pero intensa "moda de las motos" entre los varones de las clases medias más acomodadas. Se trataba, al decir de reportes de prensa, de una "juventud muy frívola", de la cual la poética del rock se separaba al despuntar la década de $1980 .{ }^{36} \mathrm{En}$ las postrimerías de la Guerra de Malvinas y, más intensificado, durante el proceso electoral de 1983, se produjo una transformación en los modos de representar a la juventud y se interpeló a los jóvenes a participar activamente del proceso de apertura. Fue allí cuando, de acuerdo a Clarín, comenzó a vivirse una "moda democracia" - algo de lo cual Gloria Guerrero se reía desde sus páginas en Humor, aunque reconociera que, en efecto, ser "frívolo ya no estaba de moda". ${ }^{37}$ Sin embargo, un año después Guerrero y otros periodistas interesados en las variaciones en las culturas juveniles se alarmaban. "Ha comenzado el momento de criar ovejas otra vez", sostenía Guerrero al comentar las colas de adolescentes para participar de un concurso de breakdance: para 1984, Michael Jackson cerraba el círculo abierto por Travolta, uno que implicaba a su criterio "la compulsión a vaciarse la cabeza y ponerse a bailar". ${ }^{38}$ Mientras esa figura del "disco" interesado por el baile aglutinaba el desprecio de roqueros y psicobolches, una segunda era más escurridiza: la del público y los artistas identificados con la New Wave y su estética "moderna". En 1982, una periodista ligada a la promoción de la música popular produjo una crónica muy negativa del concierto en el que Virus presentó Wadu Wadu, enfatizando tres aspectos que se reiterarían como una letanía para enjuiciar a "los modernos": la emulación de ondas extranjeras; la vacuidad de la alegría y el hedonismo; y el "craso comercialismo". 39 Aunque Virus pronto ganó respetabilidad entre los músicos (Spinetta y Gieco sostuvieron que, tras vencer prejuicios, empezaban a disfrutar), no sucedió lo mismo con otras bandas y sus públicos, como Zas y Soda Stéreo. Inicialmente, hasta quienes se esforzaban desde el mundo roquero por mantener un halo de "gran familia" las excluían. ${ }^{40}$ Como en otros contextos, el éxito

\footnotetext{
${ }^{36}$ Para una suerte de etnografía entre ese segmento juvenil, ver "Los peligros de la frivolidad", Clarin Revista, 14 de febrero de 1982, 4-6 y Sibila Camps, "La onda de hoy," Clarín, 23 de febrero de 1983, 25;

Para una historización del "careta", ver Manzano, The Age of Youth, cap. 8.

37 "Ahora, estamos en la moda-democracia", Clarín Revista, 21 de agosto de 1983, 8-10; Gloria Guerrero, "Los jóvenes mil usos", Humor no. 112, septiembre de 1983, 58-9.

${ }^{38}$ Gloria Guerrero, "Una extraña primavera”, Humor no. 135, septiembre de 1984.

${ }^{39}$ Sibila Camps, "Este Virus ya se lo habían pescado Los Beatles", Humor no. 74, enero de 1982, 62. Ver también "Rock nacional, del grito a la sonrisa", Clarín Revista, 18 de marzo de 1984, 4-5.

40 Gloria Guerrero, "Modern delirium: balance 1984", Humor no. 143, enero de 1985, 99-100; Carlos Polimeni, “Al rock a hacer negocios”, Clarín, 7 de marzo de 1985, 39;
} 
comercial de esas bandas las tornaban sospechosas en el mundo del rock, y definitivamente opuestas al espacio sónico, político y cultural que enmarcó a la figura del psicobolche.

Al promediar la década de 1980 e ingresar al registro escrito, la figura del psicobolche organizaba el mapa de consumos musicales, incorporando una interrogación por las relaciones entre cultura, política y juventud. Ese mapa reconocía una dicotomía básica_psicobolches y "modernos"-pero hubo muchos que intentaron circunvalarla, incluyendo a los músicos y periodistas ligados al mundo underground y al punk. Como plantearían Roberto Pettinato, Geniol o Tom Lupo, estas vertientes buscaban caminos expresivos para mantenerse fuera, "y bien lejos" de la "cosa bolche comprometida" y de los "conchetitos". ${ }^{41}$ Y lo mismo sucedía con algunos músicos más consagrados. Spinetta, por ejemplo, mientras tocaba junto a César Isella en la inauguración del año académico 1985 en la Ciudad Universitaria de la UBA, cuestionaba "la dialéctica del progresismo de la izquierda". Al hacerlo, comentaba que "yo a veces uso el concepto de psicobolche como un tipo de insulto suave". ${ }^{42}$ En boca de Spinetta, psicobolche podía ser un "insulto suave", pero no lo era entre otras franjas de la cultura del rock. Como lo sintetizaban dos periodistas, el término se había expandido como un "reguero de pólvora" hacia $1985 \mathrm{y}$, a su criterio, era indicativo de una "guerra entre quienes fueron hermanos hasta ayer no más": los artistas que se acercaban a vertientes más politizadas, por un lado; y aquellos que representaban un giro más "moderno". ${ }^{43}$ Hasta "ayer no más", las líneas de porosidad entre el rock y la música de "proyección folklórica" habían sentado las coordenadas para aquel espacio en el cual emergió la figura del psicobolche, asociada a un modo de procesar las relaciones entre juventud, cultura y política en términos de convergencia e inclusión, a tono con las demandas democráticas y con una sensibilidad y estética orientada a las solidaridades con, y memorias de, los procesos revolucionarios en América Latina. Para mediados de la década de 1980, cuando pasó al registro escrito, la figura del psicobolche estaba a punto de ser expulsada del mundo roquero (virando rápido hacia la hegemonía de los "modernos") en una dinámica que hablaba también de las dificultades para sostener convergencias en el mundo de la política y de la cultura.

\section{Madura, democrática, antiimperialista}

Si para 1985 había cristalizado la figura del psicobolche en el universo roquero, también en ese año se hilvanaron algunos hilos que hacían a su politicidad. En las elecciones legislativas, el PI (ése que, para Enrique Symns, mejor capturaba la "onda" del psicobolche) se instituyó como tercera fuerza política, obteniendo el 6 porciento de los votos a nivel nacional y una mejor performance en Buenos Aires, donde sumó cinco diputados entre la Ciudad y la Provincia, incluido su líder histórico, Oscar Alende. La elección marcó un (transitorio) giro hacia la centroizquierda del electorado urbano y, como lo detallaban crónicas posteriores, un "sólido trabajo de la muchachada, porque de allí

\footnotetext{
41 "La resistencia despreciada", El periodista de Buenos Aires no. 76, 21 de febrero de 1986, 16-7.

42 "La UBA le dio la bienvenida a sus ingresantes", Clarín, 24 de marzo de 1985, 28; Eduardo Blaustein y Eduardo Berti, "Spinetta", El Porteño no. 57, septiembre de 1986, 56-60.

${ }^{43}$ Jorge Warley y Eduardo Berti, "Rock nacional: la batalla del milenio", El Porteño no. 65, mayo de 1987, 68-70.
} 
salieron los votos". ${ }^{44}$ La "muchachada" universitaria también se mostró seducida: en las elecciones para centros de estudiantes en la UBA, el PI logró un 20 porciento del padrón electoral total y el control de cuatro centros de estudiantes (incluyendo, por supuesto, el de la carrera de Psicología). ${ }^{45}$ Se trataba del momentum de una dinámica de repolitización que despegó en 1981 y se reforzó tras la Guerra de Malvinas, nutriendo los contingentes juveniles de todas las fuerzas políticas-también de aquellas que no se sumaron al MOJUPO, como las juventudes del Movimiento al Socialismo y el Partido Obrero, por izquierda, o la de la naciente Unión del Centro Democrático, por derecha-tanto como del movimiento de derechos humanos, de las juventudes sindicales y grupos en barrios populares, amen del movimiento estudiantil secundario y universitario. En la combinación de esa dinámica de politización juvenil y las variaciones en otros tramos de las culturas juveniles - en especial, en aquel espacio sónico de convergencia-se perfiló la figura del psicobolche, expresiva de un modo de procesar demandas democráticas tamizadas por, y en tensión con, un lenguaje antiimperialista que evocaba nociones de liberación y de revolución, readecuándolas al presente de la así llamada transición.

Como parte de aquel mismo proceso de emergencia de un espacio sónico, cultural y político, los inicios de las dinámicas de repolitización juvenil pueden fecharse hacia 1981. Como lo han comenzado a detallar algunos estudios, las ramas juveniles de los partidos políticos que mantuvieron algún grado de legalidad durante la dictadura intentaron preservar un mínimo de funcionamiento, y ya para 1980 la FJC, el sector de Renovación y Cambio de la UCR, algunas variantes socialistas y otras del peronismo (como la articulada en la revista Jotapé) se animaban a avanzar en declaraciones y puntos de acuerdoreclamando, por ejemplo, la legalización de la actividad política o solidarizándose con la triunfante revolución en Nicaragua. ${ }^{46}$ En el marco de la apertura de 1981, el activismo juvenil se reforzó, tornándose visible en el movimiento estudiantil universitario y también secundario. Al reclamo contra las restricciones al sistema de ingreso y los aranceles universitarios, que fueron tomando mayor estado público, se le sumaba, en el nivel medio, la organización de eventos deportivos y culturales - estos últimos, imbricados con estéticas y sonidos de aquel espacio de convergencia - que fueron permitiendo la rearticulación del activismo. ${ }^{47}$ Una de las principales "ganadoras" de activistas nuevos en esa incipiente dinámica de repolitización fue la FJC, a su vez una de las mayores promotoras de la "unidad programática juvenil". De hecho, al lanzarse la Multipartidaria-un acuerdo entre las dirigencias de la UCR, el PJ, el PI, Partido Demócrata Cristiano y Movimiento de

\footnotetext{
44 "La elección del Partido Intransigente", Clarín, 6 de noviembre de 1985, 9.

${ }^{45}$ Ver Yann Cristal, "El movimiento estudiantil de la UBA en los '80: de la 'primavera' al desencanto", Ponencia presentada en las Jornadas Juventudes Universitarias en América Latina, ayer y hoy", Universidad de Buenos Aires, mayo de 2017.

${ }^{46}$ Mónica Beltrán, La Franja, Buenos Aires, Aguilar, 2013; María Florencia Osuna, De la 'revolución socialista' a la 'revolución democrática: Las prácticas políticas del Partido Socialista de los Trabajadores/Movimiento al Socialismo durante la última dictadura, La Plata, Libros de la Buena memoria, 2015, 123-150; Natalia Casola, El PC argentino y la dictadura militar, Buenos Aires, Imago Mundi, 2016.

${ }^{47}$ Ver Laura Luciani. Juventud en dictadura: representaciones, politicas y experiencias juveniles en Rosario, 1976-1983, La Plata, Libros de la Buena Memoria, 2017, 199-257; Guadalupe Seia, "La Universidad de Buenos Aires entre la 'Misión Ivanisevich' y la última dictadura, 1974-1983”, Tesis de Maestría, UNGSIDES, 2016.
} 
Integración y Desarrollo-la dirigencia de la FJC (cuyo partido intentó, aunque no logró, ingresar a la iniciativa) convocó a una "Multi juvenil". En abril de 1981, el primer documento conjunto de esa "Multi" reclamaba una "salida democrática" y también la liberación de presos políticos y la "verdad sobre los desaparecidos". ${ }^{4}$ Además de cimentar acuerdos básicos, desde la FJC se insistía en plantear esa "Multi juvenil" como un espacio de camaradería, que permitiera crear lazos fraternales y de amistad entre militantes provenientes de diferentes familias políticas. Por eso, quizá, la FJC celebró la presencia de militantes radicales, peronistas e intransigentes en una parrillada para conmemorar el 60 aniversario de su fundación, que terminó con un recital donde tocaron Armando Tejada Gómez y Víctor Heredia, artistas ligados al PC pero también parte del espacio sónico, político y cultural de convergencia en el que emergía el psicobolche. ${ }^{49}$

Esa inicial rearticulación de la militancia juvenil se potenció y amplificó tras la Guerra de Malvinas, que implicó no solamente la erosión del régimen militar-y el fin de la veda política en julio de 1982-sino también una insistente preocupación sobre las relaciones entre juventudes y política. Llamativamente, cinco días antes del inicio de la contienda, Clarín Revista produjo un informe sobre jóvenes y política, consultando a dirigentes políticos y sindicales - algunos de ellos, aglutinados en la "Multi" juvenil. Aunque éstos rescataran ese incipiente espacio de participación, los más coincidían con el por entonces muy joven dirigente sindical Germán Abdala, quien consideraba que las representaciones básicas de las relaciones entre juventud y política se organizaban en dos polos: o bien focalizaban en el "desinterés y la apatía", o bien se centraban en la "radicalización y la violencia", reenviando a una "generación anterior". ${ }^{50}$ En los meses siguientes, esas representaciones fueron puestas en jaque. El llamado a conscriptos fue acompañado por una oleada de participación juvenil, que implicó desde el alistamiento de miles de varones como voluntarios y la colaboración de estudiantes en la recolección de ropa o comida para los conscriptos, hasta la presencia de 60 mil jóvenes en el Festival de la Solidaridad en el estadio Obras-donde tocaron prácticamente todas las bandas y músicos de rock del momento. ${ }^{51}$ Si bien mucho más trabajo es necesario para analizar esa coyuntura, no se trataba solo de aquellos jóvenes ya inmersos en la vida de los partidos o el movimiento estudiantil, sino que se incorporaban muchos nuevos al interés por la vida pública y eventualmente por la política.

Esos jóvenes que mostraban interés por la política, en un sentido amplio, eran parte de esos "cuatro millones y medio de personas" que, como insistían los consultores políticos y periodistas, jamás habían votado. Para intentar trazar con mayor precisión sus opiniones y expectativas, Tiempo Argentino lanzó una mega encuesta en el área metropolitana de Buenos Aires (durante 85 días se reprodujeron opiniones junto a los "votos cantados") y

\footnotetext{
48 "Unidad, programa y lucha", Aquí y ahora la juventud no. 4, 16 de abril de 1981.

49 "La Multi juvenil", Aquí y ahora la juventud no. 12, 13 de agosto de 1981; "Vino, parrillada y Multi", Aquí y ahora la juventud no. 16, 8 de octubre de 1981.

50 “Informe especial: los jóvenes y la política", Clarín Revista, 28 de marzo de 1982, 4-9.

${ }^{51}$ Federico Lorenz, Las guerras por Malvinas, Buenos Aires, Edhasa, 2006; y, sobre el significado de ese festival para la "oficialización" de la cultura roquera, ver Sergio Pujol, "El rock en la encrucijada: Apuntes para una historia cultural de Malvinas," en Sergio Pujol (coord.) Composición libre: la creación musical en la Argentina en democracia, La Plata, Editorial de la Universidad Nacional de La Plata, 2015.
} 
otra, más amplia y anónima que preguntaba por "orientaciones". Esta segunda encuesta mostraba que, sobre un total de 1800 encuestados, seis de cada 10 reconocían que su interés por la política había aumentado tras Malvinas y, al identificar cuáles creían eran los problemas más urgentes, respondieron: la falta de respeto a la constitución; la falta de libertad; los problemas económicos y la desocupación; y los desaparecidos. A diferencia de sus pares de principios de la década de 1970, aseguraba el analista-encuestador, los jóvenes de los ochenta estaban más "interesados por propuestas que pudieran cumplir con la constitución y la democracia" y anotaba que, consultados sobre política internacional, habían respondido - seguramente como legado de Malvinas - que la urgencia de la Argentina era encontrar "solidaridad con América Latina". A diez meses de las elecciones-ya convocadas para octubre de 1983 - esa encuesta daba como preferido por los jóvenes al Partido Justicialista, seguido de cerca por la UCR y, más lejos, el PI y el PC. Sin embargo, Alfonsín era, ya, el "líder preferido", seguido por Oscar Alende. ${ }^{52}$ Se trataba, como todas, de una encuesta tendenciosa, pero indicativa de dinámicas concurrentes: el interés creciente de un segmento juvenil por la política, y la relevancia que tenían los reclamos democráticos y la solidaridad con Latinoamérica. Sobre esa base se re-articularon y expandieron las ramas juveniles de los partidos.

A lo largo de 1983, esas dinámicas de repolitización se enmarcaron en un lenguaje en el que primaban las nociones de convivencia e inclusión que animaron a la primera "Multi" y al naciente MOJUPO así como al espacio sónico, político y cultural de convergencia. Así, por ejemplo, al reconstruir las características de la nueva militancia universitaria en pos del restablecimiento de los centros de estudiantes en 1983, un estudiante de Psicología de la FJC indicaba que "discutimos fuerte" con militantes de otros grupos, pero que "nos reconocemos como compañeros", con lo que coincidía otro activista, enrolado en Humanismo y Liberación. Algo similar sucedía en las escuelas secundariasdonde, según un radical alfonsinista, "nos podemos putear [con un par del PI] pero también nos reconocemos como pares"- y hasta con quienes competían por afiliar en las mesas que se instalaban en las principales esquinas del país. ${ }^{53}$ Ese halo de confraternidad y convivencia es el que pretendió recuperar y modelar la experiencia del MOJUPO. En medio de la disputa electoral y cuando la Multipartidaria ya estaba disuelta, las ramas juveniles de la UCR, variantes del PJ, el PI, el PC, la Democracia Cristiana, el Movimiento de Integración y Desarrollo y segmentos del socialismo lanzaron al MOJUPO — cuestionado desde sus inicios por juventudes trotskistas. ${ }^{54} \mathrm{Su}$ primer documento, de mayo de 1983 , recuperaba algunos de los puntos de aquel ya lanzado por la "Multi" juvenil en 1981, incluyendo el reclamo por un "retorno urgente a la vida institucional", la liberación de los presos políticos y la "verdad sobre los desaparecidos", pero incorporaba otras declaraciones

\footnotetext{
52 "Preocupaciones, tendencias y la confusión", Tiempo argentino, 6 de febrero de 1983, 15-17; la encuesta del "voto cantado" arrojó cifras similares para la competencia entre los partidos mayoritarios, "El peronismo ganó el voto juvenil", Tiempo argentino, 12 de marzo de 1983, 16-7.

${ }_{53}^{3}$ Laura Sverdlik y Daniel Samailovich, "Ha nacido una nueva "tolerancia" en la universidad", Clarín Revista, 19 de junio de 1983, 4-5; "Cuando la política no está prohibida para menores", Clarín Revista, 24 de julio de 1983, 4-5; "Los jóvenes y la política", Tiempo Argentino, 8 de abril de 1983, segunda sección, 3.

${ }^{54}$ Desde la juventud del Movimiento al Socialismo, por ejemplo, se planteó que no se estaba en contra de la unidad de acción con esas otras juventudes, sino con que "se sigan las promesas demagógicas de la vieja dirigencia política", ver "Fuertes críticas en un acto del MAS", Clarín, 2 de Julio de 1983, 7.
} 
más novedosas, entre las cuales se incluía el "repudio a todo tipo de violencia como método de acción política" ${ }^{55}$ Ese rechazo a la "violencia" era, también, un modo de producir una interpretación de la historia recentísima de la década de 1970.

A partir de su critica a la "violencia" y de cultivar, al menos retóricamente, nociones de convivencia y confraternidad, quienes participaron del MOJUPO revisaron y cuestionaron los modos en que, creían, se habían articulado las relaciones entre juventudes y política a comienzos de la década de 1970 y, a partir de allí, construyeron su autorepresentación. En su condena a "todo tipo de violencia", los integrantes del MOJUPO incluían aquella originada en la represión estatal y también la que había emanado de los grupos guerrilleros, alineándose así con la matriz binaria que, como lo estudió Marina Franco, subyacía a la "teoría de los dos demonios" como clave interpretativa de la violencia política de los setenta. ${ }^{56}$ Sin embargo, ese repudio tenía usos más específicos ya que suponía una auto-representación de las juventudes políticas del contexto transicional como tajantemente diferentes a iniciativas previas-como el Encuentro de las Juventudes Políticas de comienzos de la década de 1970 que, de acuerdo a la lectura de la FJC, "sucumbió por el hegemonismo montonero" y las "divisiones estériles". 57 A diferencia de ese pasado, las juventudes políticas ahora derramaban un lenguaje centrado en la convivencia, que pretendía no abandonar los reclamos programáticos básicos. El 2 de julio de 1983, el MOJUPO llevó esa imagen a la primera de las manifestaciones de conjunto, realizada en Buenos Aires, que convocó a 35.000 jóvenes que escucharon la lectura del documento fundacional y expresaron su solidaridad con Nicaragua y su repudio a la pervivencia de Pinochet en Chile. Las crónicas de la marcha enfatizaban lo raleadas de las columnas de la Juventud Peronista (en contraposición con la década pasada) y el acompañamiento de los principales lideres adultos a esa iniciativa. "Se trata de una juventud unida, con pensamiento maduro y conducente", tranquilizaba a sus lectores la nota editorial de Clarín, y la prensa de la FJC reproducía esos mismos calificativos al considerar que la marcha "mostró la imagen sensata y madura del movimiento juvenil". 59

La experiencia del MOJUPO llevaba al centro de la escena política a unas juventudes políticas que se auto-representaban como maduras y democráticas en un contexto en el cual se reivindicaba la necesidad de dar a los jóvenes un rol protagónico en la construcción de una nueva cultura política. El 10 de diciembre de 1983, en su mensaje de apertura de la Asamblea Legislativa, el Presidente Raúl Alfonsín intentó, por un lado, sintetizar los males que - a su juicio - aquejaban a la sociedad argentina tras la última dictadura y, por otro, formular líneas maestras para dar sustentabilidad a un orden político democrático. Mientras en la síntesis de males destacaba la violación de los derechos

\footnotetext{
55 “Un documento de todos y para todos", Aquí y ahora la juventud no. 17, 2 de junio de 1983, 8.

${ }^{56}$ Marina Franco, "La teoría de los dos demonios en la primera etapa de la posdictadura", en Marina Franco y Claudia Feld (dirs..), Democracia hora cero: actores, políticas y debates en los inicios de la posdictadura, Buenos Aires, Fondo de Cultura Económica, 2015, 23-79.

57 "Un arma cargada de futuro", Aquí y ahora la juventud no. 17, 2 de junio de 1983, 5; ver también "La Jotapé sin Perón", El periodista de Buenos Aires no. 4, 6 de octubre de 1984.

58 “35.000 personas en la marcha por la democracia”, Clarín, 3 de julio de 1983. Entre los líderes que se sumaron estaban Oscar Alende, Antonio Cafiero, Hipólito Solari Yrigoyen, Augusto Conte y Athos Fava.

59 "La marcha de las juventudes", Clarín, 4 de julio de 1983, 9; "Dueños de nuestro futuro", Aquí y ahora la juventud no. 19, 6 de julio de 1983, 5.
} 
humanos, la desindustrialización, la pobreza y la deuda externa, precisaba que el nuevo orden necesitaba más que la vigencia del estado de derecho: su continuidad requería la movilización popular. "La democracia moviliza y el régimen desmoviliza," sostenía, y agregaba: "el régimen se ocupa de la desmovilización de la juventud. La democracia atiende a la movilización de la juventud". Antes que otro segmento social o cultural, Alfonsín eligió nombrar a la juventud para trazar una línea divisoria entre el pasado del "régimen" y el presente que inauguraba. ${ }^{60}$ Además de ser parte de un intento refundacional-y del trazado de esa "frontera política" que ha analizado Gerardo Aboy Carlés-la interpelación de Alfonsín a los jóvenes y, en paralelo, la configuración de la juventud como agente de cambio, tenía un anclaje más inmediato: su propia candidatura, primero en las elecciones internas y luego en las generales, fue sostenida por el activismo juvenil de la Junta Coordinadora. ${ }^{61}$ Un representante de ese núcleo, Jesús Rodríguez, fue elegido diputado en 1983 con solo 28 años. Activo en el MOJUPO, Rodríguez gestionó un encuentro de las dirigencias juveniles con Alfonsín, en el cual le entregaron un documento en el que destacaban que "preferimos el camino de la participación y de la lucha a la violencia terrorista y las vanguardias estériles que pretendieron desviar a sectores juveniles a un falso camino de lucha llevándolos a la derrota". ${ }^{62} \mathrm{La}$ insistencia en auto-representarse como parte integral, y hacedora, de una nueva democracia suponía distanciarse de una articulación previa de las relaciones entre juventudes y política, a la cual la dirigencia del MOJUPO definía marcada por la "violencia terrorista" y las "vanguardias estériles". Sin embargo, ni siquiera el radical Rodríguez podía echar por tierra parte del lenguaje de aquella juventud de los setenta. Al igual que sus pares en la FJC y el PI, por ejemplo, la formación política de los radicales alfonsinistas incluía la creencia de que la "contradicción fundamental" era entre "el pueblo argentino por un lado, y el complejo antinacional, monopólico e imperialista por otro". ${ }^{63}$ Dentro de ese universo, términos como "liberación nacional" y "revolución" tenían peso aún: "la juventud de hoy está convencida que el auténtico camino para la liberación nacional es la democracia", sostenía Rodríguez tras ser elegido diputado, y concluía que "la revolución hoy, aquí y ahora significa la estabilización de la democracia." 64

La experiencia del MOJUPO, más allá de sus capacidades reales de movilización, fue indicativa tanto de la voluntad de convergencia como de las posibilidades y límites de combinar dos lenguajes, el de la democracia y el de la revolución. En tal sentido, en el bienio 1984-85 las actividades del MOJUPO se limitaron a aquello que parecía unificar esos lenguajes y programas: la denuncia de las injerencias del Fondo Monetario

\footnotetext{
60 "Mensaje del Dr. Raúl Alfonsín a la Honorable Asamblea Legislativa", en Discursos y mensajes presidenciales, vol. 1, Buenos Aires, Secretaría de Prensa de la Presidencia de la Nación, 6.

${ }^{61}$ Beltrán, La Franja, cap. 4. Para el proyecto refundacional de Alfonsín, ver Gerardo Aboy Carlés, Las dos fronteras de la democracia argentina, Rosario, Homo Sapiens, 2001.

62 "Entregaron a Alfonsín un documento las juventudes políticas", Clarín, 4 de diciembre de 1983, 4.

63 Junta Coordinadora Radical, La contradicción fundamental, Buenos Aires, s/e, 1984. Se trata de una reedición de esta obra, sin firma, publicada originalmente a principios de la década de 1970. Como lo señalaron otros autores, el libro/panfleto reconoce matrices del maoísmo pero en su versión de la década de 1980, quedan excluidas las referencias a la revolución.

64 "El diputado del blue jean tiene la palabra", Tiempo argentino, 7 de noviembre de 1983, segunda sección, 2-3; "Estabilizar la democracia", Aquí y ahora la juventud no. 27, 9 de noviembre de 1983, 9.
} 
Internacional (FMI) y la crisis de la deuda externa, por un lado, y la solidaridad con Nicaragua, por otro; ambas aunadas en posiciones antiimperialistas. En julio de 1984, el MOJUPO llamó a una segunda movilización, que se denominó "marcha contra la dependencia", a la cual asistieron 70 mil jóvenes que corearon contra la deuda externa y cuestionaron a la "patria financiera" y las presiones del FMI. ${ }^{65}$ Tras esa demostración de unidad, en ese punto fundamental - que ponía el acento en un reclamo crítico al gobierno alfonsinista-las aguas empezaron a partirse: mientras los segmentos de las juventudes radicales acompañaban a su gobierno en posiciones acuerdistas (llegando al punto que varios líderes, incluyendo a Rodríguez, se entrevistaran en buenos términos con Nelson Rockefeller en enero de 1985), desde el PI, la FJC y grupos peronistas se les reclamaba definiciones más tajantes sobre el rumbo económico en general, y el pago de la deuda en particular. ${ }^{66}$ A diferencia de las discrepancias crecientes en este punto, la solidaridad con la revolución nicaragüense continuó como punto de unidad. Si bien la FJC fue la fuerza que con mayor sistematicidad vehiculizó iniciativas de solidaridad-como el envío de sucesivas brigadas juveniles para el corte de café — de alguna u otra forma todas las ramas juveniles que integraban al MOJUPO participaron de esos emprendimientos. ${ }^{67}$ Esas solidaridad servía, también, para trazar fronteras con otras fuerzas políticas que empezaban a crecer entre los jóvenes, especialmente universitarios. Así, por ejemplo, a fines de 1984, un congreso que se encontraba definiendo las nuevas autoridades de la Federación Universitaria de Buenos Aires - a la sazón, con una mayoría de Franja Morada-levantó sus sesiones para asistir a la Marcha de la Resistencia organizada por las Madres de Plaza de Mayo, pero antes produjo un despacho cuyo primer punto era expresar la solidaridad con "el pueblo nicaragüense ante una eventual invasión norteamericana". El despacho tuvo el apoyo de todas las agrupaciones presentes - en su gran mayoría, expresiones universitarias de los partidos que integraban al MOJUPO - aunque la disconformidad expresa de los representantes de Unión para la Apertura Universitaria (UPAU), rama de la Unión del Centro Democrático (UCD) que se oponía a esa expresión de solidaridad. ${ }^{68}$

La solidaridad con Nicaragua y el uso de ciertos términos que servían para organizar el mapa, las demandas y hasta las identidades políticas-“dependencia" y "liberación", por caso - hablaban de la continuidad de un imaginario y un lenguaje de la revolución, que se combinaba también con las demandas democráticas que enfatizaban en la convivencia. Fue en ese cruce donde se instalaba aquel espacio sónico, político y cultural de convergencia y donde emergió y cristalizó la figura del psicobolche. Se trató de un tiempo corto, que abarcó el lustro iniciado en 1981 y que para 1985 parecía haber alcanzado su cúspide y ya mostraba, de acuerdo a algunos observadores, signos de debilitamiento. Así, por ejemplo, una cultora de aquel espacio y de las dinámicas de

\footnotetext{
65 "Numerosa presencia de las juventudes políticas en un acto por la deuda", Clarín, 23 de junio de 1984, 6; "La juventud contra la dependencia", Luchar no. 9, junio de 1984.

${ }^{66}$ Alfredo Leuco, "Semana crucial para el MOJUPO", Clarín, 11 de febrero de 1985, 9; "Bases para un nuevo país", El periodista de Buenos Aires no. 35, 30 de mayo de 1985, 5-7. Sobre las entrevistas de los líderes juveniles radicales con Rockefeller y su impacto en el MOJUPO, ver Alfredo Leuco y José Antonio Díaz, Los herederos de Alfonsín, Buenos Aires, Puntosur, 1987.

${ }^{67}$ Ver Daniela Fernández Hellmud, Nicaragua debe sobrevivir, Buenos Aires, Imago Mundi, 2015.

68 "La FUBA con Nicaragua", Clarín, 22 de diciembre de 1984, 31.
} 
repolitización, la periodista Sandra Russo, hacía uso del termino "pasota", muy en boga entre los analistas de la transición española, para referirse a lo que veía como "signos inequívocos del retorno al individualismo entre los jóvenes que pasan de todo, que creen que nada tiene sentido". ${ }^{69}$ Esos signos se profundizaron en 1986, cuando técnicamente el MOJUPO se disolvió ante la imposibilidad de seguir sosteniendo acuerdos en el marco del deterioro de la situación económica y de los posicionamientos del gobierno de Alfonsín frente a la "cuestión militar". Alfonsín ya había sentado las bases de su política de juzgamiento a los militares en su campaña electoral, pero fue en 1986 y 1987, en medio de asonadas militares, cuando el gobierno promovió las leyes de "Punto Final", que ponía fin a nuevos juzgamientos, y de "Obediencia Debida", que exceptuaba de juzgamiento por violación a los derechos humanos a los militares de menor jerarquía. Contemporáneamente, varios núcleos juveniles entendieron que esas leyes representaban un desvío fundamental con respecto a las políticas tendientes a la verdad y la justicia que la nueva democracia había prometido y esa creencia estuvo en la base, por ejemplo, de fraccionamientos dentro de la Franja Morada. ${ }^{70}$ Para 1987, todos esos signos críticos se conjugaron: el oficialismo perdió las elecciones legislativas y provinciales y, la Unión del Centro Democrático (UCD) - una fuerza de derecha liberal-ocupó el tercer lugar que solo dos años antes ocupara el PI. Una tendencia similar se reprodujo en la UBA, donde en las elecciones de centro de estudiantes la rama estudiantil de esa fuerza, UPAU, estuvo a punto de arrebatarle la elección a la Franja Morada con una campaña marcadamente anti-política y supuestamente "sindical". El electorado, general y universitario, había girado hacia la centro-derecha. Derechización, descreimiento y percepción de una crisis generalizadapolítica, económica - fueron el telón sobre el cual, en el último tercio de la década, se deconstruyó la figura del psicobolche, atada a un tiempo que se iba.

\section{"La revolución no es más que otra canción de Silvio Rodríguez"}

Antes de parodiar al psicobolche contando la historia del académico sueco, Marcelo Figueras había trazado una breve historia de los nuevos periodistas que, como él, empezaban a pulular por las redacciones en el último tercio los años ochenta. A su criterio, eran "los adolescentes de la dictadura" y, usando la primera persona del plural, precisaba que "crecimos respirando artificialmente (...) somos profundamente individualistas (...) a la vez reaccionarios y bolches de cuidado". ${ }^{71}$ En la redacción donde trabajaba, ese nosotros incluía también a los escritores Alan Pauls y Daniel Guebel-quienes hacían critica de teatro y cine-y otros periodistas de la misma cohorte etaria participaban de otras redacciones, como Jorge Dorio, Claudio Zeiger y Gabriel Pasquini en El porteño. En paralelo, también en 1987 el joven aspirante a escritor y periodista Diego Lerer trazaba un perfil del estudiantado de una de las carreras "estrella" de la segunda mitad de la década: Ciencias de la Comunicación. Al hacerlo, remarcaba que se trataba de una "generación

\footnotetext{
${ }^{69}$ Sandra Russo, "Subiendo línea: se viene el pasotismo", Humor no. 152, junio de 1985, 100.

70 "La juventud radical", El periodista de Buenos Aires No. 110, 17 de octubre de 1985, 6; "Que chances tiene el punto final? El periodista de Buenos Aires No. 114, 14 de noviembre de 1986, 4-5; "Los radicales de la discordia" El periodista de Buenos Aires No. 128, 20 de febrero de 1987, 42.

${ }^{71}$ Marcelo Figueras, "Esos chicos peligrosos”, Humor no. 194, abril de 1987, 97-8.
} 
posterior al proceso" y que constituía una suerte de "psicobolche de la última ola, o postpsicobolche": a diferencia de sus predecesores, éstos idolatraban los filmes de Pedro Almodóvar y el rock under y tenían "mayor inclinación al placer". ${ }^{72}$ En el encuentro entre esos periodistas que habían sido "adolescentes de la dictadura" y lectores que, como Lerer, reivindicaban una adscripción a una "generación posterior" se produjo también el espacio en el cual la crítica más mordaz de la figura del psicobolche tuvo lugar. Se trató de una deconstrucción de esa figura y, a partir de ella, de la producción de una "memoria" de las relaciones entre juventudes y política en el contexto transicional, además de una crítica emergente a las dinámicas de despolitización y apatía en el último tercio de la década. Al hacerlo, algunos de ellos también introdujeron una evaluación de la cultura de izquierda y de las transformaciones en el universo de creencias y prácticas que se subsumían en lo "light", algo que se tornó evidente a escala local en el contexto del Festival de Amnesty en octubre de 1988 que abrió la posibilidad para ventilar públicamente cuán diferente se veía la militancia juvenil de fines de la década vis-a-vis la de comienzos de la misma.

Existía un consenso en la deconstrucción de la figura del psicobolche: pertenecía a un pasado muy reciente, que ya era otra época cultural y política. Dorio, así, puntualizaba que "se lo debemos a los militares para la época de Malvinas", mientras que Gabriel Pasquini, en sus "memorias de un psicobolche", coincidía al comentar lo rápido que se había "pasado a la nostalgia" ya que, afirmaba, "ahora encontrase con amigos es hablar de 'aquel 1982', cuando podíamos albergar la totalidad del mundo desde el colegio secundario". Ambos reponían, a la vez, los gustos culturales que organizaban el mundo psicobolche: mientas Pasquini recordaba que en "ese 82 teníamos a mano a Viglietti y al rock nacional, y no sabíamos nada de Virus o de Soda Stéreo", Dorio satirizaba más e incluía en la lista a las preferencias poéticas (Neruda, Benedetti) y abundaba en la lista de las preferencias musicales, incorporando también a "Mercedes Sosa, Zupay, Baglietto" y, por supuesto, el omnipresente Silvio Rodríguez. Y si hasta aquí puede insinuarse sólo una reconstrucción costumbrista, en ambas intervenciones destilaba también un intento más mordaz de satirizar los límites del psicobolchismo y, con él, de la cultura política que hizo y vivió un segmento juvenil durante la transición. Dorio era punzante: "el psicobolche", concluía, "ha aprendido las ventajas de la democracia formal, y ya sabe que hay que escuchar al prójimo, aunque diga tantas pavadas como él mismo". Mofándose de los modos en que se habían instalado las muy mentadas nociones de pluralismo y convergencia, remarcaba así los limites de esa pretendida conciencia democrática. Pasquini iba un paso más allá: con el correr de los años ochenta, sostenía, el psicobolche experimentó y representó una suerte de "esquizofrenia entre el mundo que participa y los mandatos nuevos y heredados". A la compulsión social al consumo se le sobre-imponían, en esa interpretación, el cultivo de los mandatos democráticos y de revolución. Se producía así un desfasaje - que, en su interpretación, fue crucial para que el propio término adquiriera sentido-por el cual "se comenzó a sentir que la revolución no es más que otra canción de Silvio Rodríguez". 73

\footnotetext{
72 Diego Lerer, "La postintelectualidad", Cerdos \& Peces no. 15, agosto de 1987.

${ }^{73}$ Gabriel Pasquini, "Memorias de un psicobolche", El porteño no. 79, Julio de 1988, 61-3; Dorio, "La irresistible levedad del psicobolche”, El porteño no. 77, mayo de 1988
} 
Para 1987, la figura del psicobolche reenviaba a otra época y permitía, en algunas de las visiones más satíricas, evaluar como un anacronismo el hecho de ser joven y de izquierda, o pertenecer a una cultura de izquierda como se había configurado en el contexto transicional. Así, en su intervención en torno a la deconstrucción de esa figura, la revista Cerdos \& Peces produjo un "suplemento especial" denominado "El bolcheño" (combinando "bolche" con El porteño) en el cual una decena de notas ficcionales, firmadas - con sus nombres ligeramente cambiados - por quienes eran supuestamente las plumas faro del universo psicobolche (los periodistas Eduardo Aliverti nombrado como "Alaborto" o Jorge Lanata, nombrado como "La Rata") hacían referencia a "noticias" de la semana anterior. Mientras el ficcional Alaborto le hacía una entrevista a un-también ficcional-psicoanalista que había inventado una escuela de "psicoanálisis decorativo" (que consistía en "sesiones de 5 minutos por ocho australes"), el ficcional La Rata narraba los avatares de un encuentro de cinco días de "talleres y ponencias" en el Teatro San Martín, cuyo panel de cierre habría terminado en tumulto. La pregunta de cierre giraba en torno al "qué es ser de izquierda" y nadie le habría encontrado una respuesta satisfactoria, ante lo cual se habría armado una batahola donde "volaron libros de Benedetti, casetes de Silvio Rodríguez y patadas, siempre con el pie izquierdo". ${ }^{74}$ La mordacidad y la sátira de esas viñetas sobre el universo psicobolche ponían el acento en la solemnidad y el acartonamiento que atravesaba la cultura de izquierda, un espacio al que se representaba por contraposición a otra opciones que-como proponía la revista-podían tener los jóvenes para "revolucionar su vida cotidiana". En el mismo sentido opinaba, también en 1987, un músico que participó de aquel espacio sónico, político y cultural de convergencia de la primera parte de la década: Fito Páez. Al lanzar su tercer LP, Ciudad de pobres corazones (que, de acuerdo a la critica, marcaba un giro estético y musical importante), Gloria Guerrero le preguntó por qué no había ido a un recital en solidaridad con Nicaragua (al que había sido invitado), y Páez contestó que "estoy medio descreído de la moral y la cultura" pero, por sobre todo, "cansado de esa cosa de izquierda, gente sin swing". 75 "Gente sin swing” era otro modo de referir a lo anquilosado que aparecía el universo de referencias que la figura del psicobolche permitía encapsular.

Mientras la figura del psicobolche reenviaba a otra época, también permitía auscultar las novedades de la segunda mitad de la década en las relaciones entre cultura, política y juventud. Uno de los signos novedosos era ese descreimiento del que hablaba Fito Páez, y más concretamente el alejamiento de los jóvenes de la vida política en partidos y movimiento estudiantil. A comienzos de 1988, un informe basado en entrevistas a "viejos jóvenes" militantes de Renovación y Cambio de la UCR, el PJ y el PI comenzaba planteando que "hace no demasiado tiempo, una camada juvenil se sumó a la política, a los partidos, donando parte completa de su tiempo libre a la 'vida', la 'revolución' o el "cambio", pero que muchos de esos jóvenes habían desertado. Uno de los entrevistados era Ernesto Semán, quien fuera uno de los responsables de la rama secundaria del PI, y planteaba que no solamente su partido había entrado en crisis, sino que él "había entrado en

\footnotetext{
74 “El bolcheño: Jorge La Rata, 'Donde queda la izquierda' y Eduardo Alaborto, 'Se curan almas por ocho australes", Cerdos \& Peces no. 15, agosto de 1987.

75 "Si hay que brillar, brillaremos", Humor no. 202, agosto de 1987, 83-5.
} 
crisis con su partido, con esa forma sacrificial, psicobolche, de la militancia". ${ }^{76}$ En ese mismo 1988, Pablo Avelluto (el actual Ministro de Cultura de la Nación) lanzó la primera piedra en un debate en la revista $E l$ porteño al escribir un mapa de los gustos juveniles, asociando la participación política a la "nueva canción latinoamericana" y, a ambas, con el pasado que "ya no vuelve y encima me harta". Algunos periodistas usaron el término "postmoderno" como insulto para descalificar esa posición-y en particular ese hartazgoaunque otros, como Claudio Zeiger, intentaban mediar, proponiendo "superar la dicotomía psicobolche vs. postmoderno". ${ }^{77}$ Ese debate ponía el acento en el malestar, aunque también en la percepción de una novedad cuya asimilación resultaba difícil. El término "postmoderno", al menos en su irrupción inicial en estos temas, indicaba tanto consumismo y frivolidad (retomando sentidos del término "moderno" en su relación con las culturas juveniles de la primera mitad de la década) como apatía y superficialidad. En un comentario sobre las elecciones estudiantiles de 1988 en la UBA, un periodista contaba la anécdota de un dirigente radical que llamaba a sus correligionarios a no ensuciar las paredes durante la campaña: "todo muy light, muy postmoderno", opinaba. ${ }^{78}$

La convicción de que todo se había vuelto "light" recorrió buena parte del periodismo interesado en juventudes, cultura y política hacia finales de la década, y un punto culmine fue el contexto del Festival de Amnesty. En octubre de 1988, la gira mundial denominada "Derechos humanos, ya" cerró en el estadio de River Plate, con la presencia de Sting, Peter Gabriel y Bruce Springsteen, además de los locales Fito Páez, Charly García y León Gieco. El Festival ya venía despertando interés desde mitad de año: se agotaron rápidamente 80 mil entradas $\mathrm{y}$, desde una pluma ligada a la música popular, se cuestionaba el involucramiento de multinacionales como sponsors, además de la negativa de los organizadores a convocar a artistas de proyección folklórica. ${ }^{79} \mathrm{Si}$ bien algunas crónicas del recital recalcaban la presencia de militancia juvenil, desde los partidos de izquierda hasta la Franja Morada, una crítica más mordaz se enfocó en otras vetas de la dimensión política del Festival ${ }^{80}$ Así, un número especial de El porteño tomó como eje al Festival para avanzar en una interpretación de los cambios en la cultura de izquierdas, especialmente en su declinación juvenil, y el título general del informe era, ni más ni menos, que "los militantes yogurt". Claudia Pasquini, por ejemplo, ironizaba que entre los jóvenes presentes en el Festival prevalecía la creencia en "una utopía blandita, querible, de buena conciencia, que ama a los niños y a los helechos", imágenes con las que intentaba sintetizar nociones sobre una nueva ética a la cual también refería como "liberal, antiautoritaria". En ese informe no se contraponía a los jóvenes portadores de esa "utopía blandita" a los jóvenes de la década de 1970, sino a los psicobolches de los ochenta. "Aquellos barbudos y simpáticos del PI”,

\footnotetext{
76 “Adiós al partido", El periodista de Buenos Aires no. 173, 8 de enero de 1988, 9-11.

${ }^{77}$ Pablo Avelluto, "Esos raros peinados nuevos", El porteño no. 77, mayo de 1988, 51-3; "Discuten los de veinte: el tesoro de la juventud”, El porteño no. 78, junio de 1988.

${ }^{78}$ Marcelo Helfgort, “El look 'tranqui' de los ochenta”, El porteño no. 77, mayo de 1988.

${ }^{79}$ Ver Rodrigo Tarruela, "Derechos humanos sin folklore”, Humor no. 224, Julio de 1988, 72.

${ }^{80}$ Para una crónica comentando la presencia de jóvenes militantes de partidos, ver "Política y derechos humanos", Clarín, 17 de octubre de 1988, 47.
} 
sostenía un articulista, "fueron los últimos en creer en algo más duro". ${ }^{81}$ Irónicamente, esos psicobolches satirizados como meros consumidores de una estética revolucionaria terminaron, por contraposición, identificados como los últimos revolucionarios tout court.

\section{Conclusiones}

La figura del psicobolche constituye una vía de entrada para comenzar a capturar las relaciones entre juventud, cultura y política—especialmente de izquierda — en la Argentina de la década de 1980. Desde una perspectiva metodológica, el abordaje de esa figura impulsa a tender puentes entre la historia cultural y la historia política (vectores que suelen escindirse en los estudios de historia reciente en la Argentina) ya que, en cuanto figura reconocible - y, luego, satirizable - el psicobolche se delineó en las intersecciones y los bordes críticos de una cultura de izquierdas. Asimismo, esta figura - y su evocación de las relaciones entre juventud y política_- permiten trazar de modo más preciso una cronología de la transición, las tensiones entre diversos lenguajes políticos en ese contexto, y los modos en que comenzó a procesarse - cultural y políticamente - el "desencanto".

Los "ochenta del psicobolche" fueron, en lo sustancial, el lustro que se inició en 1981 y se cerró en 1986, en el cual se desplegaron dos dinámicas interrelacionadas: la formación de un espacio sónico, político y cultural que denominé como de convergencia, y la emergencia de espacios de articulación entre las juventudes políticas, que también apuntaban a sostener convergencias. Ambas supusieron modos de generar identificaciones y, también, exclusiones. En el caso del espacio sónico, desde 1981 - a partir del Encuentro de Música Popular, por ejemplo_-se fue gestando una confluencia entre vertientes de la cultura roquera con "música de proyección folklórica" que señalaban la voluntad de creación de sentidos de inclusión tamizados por un renovado latinoamericanismo, con la celebración de, y la solidaridad con, procesos revolucionarios-como el de Nicaragua. Ese espacio se delineó también por oposición a otros, donde irradiaban otras figuras juveniles, como "el joven disco" o, más crucialmente, el "moderno", frente a las cuales la del psicobolche adquiría sentidos. Irradiando en, y desde, ese espacio sónico, cultural y político, el psicobolche entroncó a su vez en la articulación de las juventudes políticas. Ya desde 1981, con la formación de aquella primera "Multi" juvenil, y luego con la experiencia del MOJUPO, los llamados a la convivencia y la unidad fueron mandatos a tono con el proceso de apertura democrática que permitieron el trazado de vínculos específicos entre juventudes y política en el marco transicional. Esos vínculos también fueron excluyentes: de los "extremos" del espectro político (el trotskismo y las juventudes liberales, por ejemplo) y también de las resonancias de experiencias pasadas, notablemente setentistas, a las cuales al menos los dirigentes del MOJUPO no dudaban en calificar como "terroristas", "vanguardistas", y "estériles".

La figura del psicobolche aporta pistas para poder abordar las transfiguraciones de la cultura de izquierda. Si bien en este punto la historiografía tiene prácticamente todo por

\footnotetext{
81 "Dónde están los barbudos de entonces" y Claudia Pasquini, "Del monte al helecho", El porteño no. 82, octubre de 1988; ver también "Ellos no bailan solos", El periodista de Buenos Aires no. 223, 30 de diciembre de $1988,33-5$.
} 
hacer-incluyendo análisis pormenorizados de grupos y partidos, coyunturas específicas, posicionamientos frente a cuestiones internacionales, o relaciones con movimientos sociales - una aproximación a las relaciones entre juventud, cultura y política de izquierda a través del psicobolche invita a profundizar la investigación sobre la producción de interpretaciones y memorias sobre los setenta en la inmediata post-dictadura y, también de modo significativo, a intentar comprender con mayor precisión cómo se solaparon los lenguajes asociados a la revolución (y, claro está, a los setenta) con aquellos más noveles, centrados en la democracia. En este sentido, conviene recordar que, en 1984, aquellos integrantes del MOJUPO que se enfilaban con el partido gobernante, a la vez que muy posiblemente fueran las plumas detrás de los epítetos de "vanguardista" o "terrorista" para referir a los militantes de los setenta, no podían - quizá, todavía - echar por la borda otras resonancias setentistas. De hecho, los términos "revolución" o "liberación social" no desaparecieron del vocabulario político juvenil, sino que se buscaba una readecuación de los mismos al lenguaje de la democracia.

Tanto en el terreno propiamente político como en el político-cultural ligado a la música, esas experiencias de convergencia (entre distintas familias políticas, entre distintas estéticas y sonidos) fueron desvaneciéndose y, en el último tercio de la década de 1980, eclipsándose totalmente ante la percepción de apatía, desencanto y crisis. Mientras que las vertientes psicobolches eran "expulsadas" del mundo del rock (ante transformaciones que dieron con la predominancia de las expresiones más ligadas a "los modernos"), el MOJUPO se fragmentó hasta desaparecer al calor de la creciente crisis económica y los vaivenes de la "cuestión militar", que volvieron intolerable la convergencia de fuerzas de izquierda con el partido de gobierno en un mismo espacio. La aparente crisis de las coordenadas que habían posibilitado aquellas convergencias cristalizaron en 1987, cuando desde el periodismo cultural y de rock, una nueva cohorte produjo su crítica satírica, por momentos mordaz, de la figura del psicobolche y lo que ella evocaba de un pasado muy reciente y del supuesto tono anacrónico de la cultura de izquierda en la Argentina. En la zona cultural representada por la madeja de revistas aquí analizadas, esa crítica a la cultura de izquierda y sus declinaciones juveniles se recostó sobre una representación del psicobolche epitomizado como "gente sin swing", como figura anquilosada en una estética y un estilo de hacer política — a veces tildado también como "sacrificial"— del que muchos jóvenes antes involucrados comenzaban, ya, a descreer. La dinámica de descreimiento comprometía tanto al lenguaje de la revolución como al de la democracia, y señalaba el despegue de una interrogación por lo que empezaba a llamarse "postmoderno". En parte, este recorrido permite entrever cómo las discusiones sobre la "crisis de la izquierda", al menos en esta zona de la cultura argentina, fueron anteriores al cimbronazo producido por los acontecimientos europeos de 1989 o a la derrota electoral del Sandinismo en 1990. La percepción de esa crisis, asimismo, recuperaba hilos del campo de la cultura y de la política, y la de-construcción de la figura satírica del psicobolche fue una de las plataformas en las cuales comenzó a tramitarse. 


\section{Referencias bibliográficas}

Gerardo Aboy Carlés, Las dos fronteras de la democracia argentina, Rosario, Homo Sapiens, 2001. Patrick Barr-Melej, Psychedelic Chile, Chapel Hill, University of North Carolina Press, 2017. Mónica Beltrán, La Franja, Buenos Aires, Aguilar, 2013.

Rafael Blanco y Pablo Vommaro, "Otros caminos, otros destinos: transformaciones en los espacios y prácticas cotidianas de participación juvenil en los años ochenta", en Melina Vázquez, Pablo Vommaro, Pedro Nuñez y Rafael Blanco (comps), Militancias juveniles en la Argentina democrática, Buenos Aires, Imago Mundi, 2017, 1-25.

Mara Burkart, De Satiricón a HUMOR: risa, cultura y políitca en los setenta, Buenos Aires, Miño y Dávila, 2016.

Paula Canelo, El proceso en su laberinto: la interna militar de Videla a Bignone, Buenos Aires, Prometeo, 2008.

Natalia Casola, El PC argentino y la dictadura militar, Buenos Aires, Imago Mundi, 2016.

Isabella Cosse, Mafalda: historia social y política, Buenos Aires, Fondo de Cultura Económica, 2015.

Yann Cristal, "El movimiento estudiantil de la UBA en los '80: de la 'primavera' al desencanto", Ponencia presentada en las Jornadas Juventudes Universitarias en América Latina, ayer y hoy", Universidad de Buenos Aires, mayo de 2017.

Julián Delgado, "No se banca más: Serú Girán y las transformaciones musicales del rock en la Argentina dictatorial," Revista Afuera: Estudios de Crítica Cultural, no. 15, 2015.

Geoff Eley, Forging Democracy: the History of the Left in Europe, 1850-2000, New York, Oxford University Press, 2002.

Daniela Fernández Hellmud, Nicaragua debe sobrevivir, Buenos Aires, Imago Mundi, 2015.

Marina Franco, "La teoría de los dos demonios en la primera etapa de la posdictadura", en Marina

Franco y Claudia Feld (dirs..), Democracia hora cero: actores, políticas y debates en los inicios de la posdictadura, Buenos Aires, Fondo de Cultura Económica, 2015, 23-79.

Northop Frye, Anatomy of Criticism: Four Essays, Hardomsworth, Penguin, 1990.

Irina Garbatzky, Los ochenta recienvivos: poesía y performance en el Río de la Plata, Rosario, Beatriz Viterbo, 2013.

Valeria Garrote, "La estrategia de la alegría en los colectivos artísticos de la dictadura y la postdictadura, España y Argentina (1973-1989)", Tesis doctoral inédita, Rutgers University, 2013.

Marina Larrondo y Alejandro Cozachcow, "Un llamado a la unidad: la experiencia del Movimiento de Juventudes Políticas (MOJUPO) en la transición a la democracia", en Vázquez et al, Militancias juveniles, 51-71.

Florencia Levín, Humor en tiempos de represión: Clarín, 1973-1983, Buenos Aires, Siglo XXI, 2013.

Federico Lorenz, Las guerras por Malvinas, Buenos Aires, Edhasa, 2006.

Daniela Lucena y Gisela Laboureau (eds.), Modo mata moda: Arte, cuerpo y (micro) política en los 80, La Plata, EDULP, 2016.

Laura Luciani. Juventud en dictadura: representaciones, politicas y experiencias juveniles en Rosario, 1976-1983, La Plata, Libros de la Buena Memoria, 2017.

Valeria Manzano, The Age of Youth in Argentina: Culture, Politics, and Sexuality from Perón to Videla, Chapel Hill, University of North Carolina Press, 2014

Valeria Manzano, “'Contra toda forma de opresión': sexo, política y clases medias juveniles en las publicaciones de humor de los tempranos setenta", Sociohistórica, vol. 29, noviembre de 2011.

Vania Markarian, El '68 uruguayo: entre cócteles molotov y música beat, Bernal, Universidad Nacional de Quilmes, 2012. 
María Matilde Ollier, De la revolución a la democracia, Buenos Aires, Siglo XXI, 2009.

María Florencia Osuna, De la 'revolución socialista' a la 'revolución democrática: Las prácticas políticas del Partido Socialista de los Trabajadores/Movimiento al Socialismo durante la última dictadura, La Plata, Libros de la Buena memoria, 2015.

Mariano Plotkin, Freud en las Pampas: Orígenes y desarrollo de una cultura psicoanalítica en la Argentina (1910-1983), Buenos Aires, Sudamericana, 2003.

Sergio Pujol, "El rock en la encrucijada: Apuntes para una historia cultural de Malvinas," en Sergio Pujol (coord.) Composición libre: la creación musical en la Argentina en democracia, La Plata, Editorial de la Universidad Nacional de La Plata, 2015.

Guadalupe Seia, "La Universidad de Buenos Aires entre la 'Misión Ivanisevich' y la última dictadura, 1974-1983", Tesis de Maestría, UNGS-IDES, 2016.

Beatriz Trastoy, "Teatro Abierto 1981: un fenómeno social y cultural”, en Osvaldo Pelletieri (ed.), Historia del teatro argentino, 1976-1996, Buenos Aires, UBA/Galerna, 2000.

Carlos Ulanovsky, Paren las rotativas, vol. 2, Emecé, 2005;

Viviana Usubiaga, Imágenes inestables: Artes visuales, dictadura y democracia en Buenos Aires, Buenos Aires, Edhasa, 2012.

Pablo Vila, "Rock nacional: crónicas de la resistencia juvenil", en Elizabeth Jelin, ed. Los nuevos movimientos sociales/1, Buenos Aires, Centro Editor de América Latina, 1985.

\section{Fuentes primarias}

\section{Libros, panfletos, estadísticas}

Raúl Alfonsín, Mensajes presidenciales, vol. 1-2, Presidencia de la Nación, Secretaría de Prensa, 1984.

Junta Coordinadora Radical, La contradicción fundamental, Buenos Aires, s/e, 1984.

Alfredo Leuco y José Antonio Díaz, Los herederos de Alfonsín, Buenos Aires, Puntosur, 1987.

Mario Toer, Cómo son los estudiantes, Buenos Aires, Catálogos, 1990, 76.

Universidad de Buenos Aires, Censo general de alumnos 1968, Buenos Aires, s/e, 1970.

Universidad de Buenos Aires, Censo general de alumnos 1988, Buenos Aires, s/e, 1991.

\section{Artículos periodísticos (solo se mencionan los que tienen firma)}

Pablo Avelluto, "Esos raros peinados nuevos", El porteño no. 77, mayo de 1988, 51-3.

Eduardo Blaustein y Eduardo Berti, "Spinetta”, El Porteño no. 57, septiembre de 1986, 56-60.

Sibila Camps, "Un volcán llamado Serrat", Clarín espectáculos, 4 de junio de 1983, 2.

Sibila Camps, "El canto, la poesía, el espectáculo", Clarín espectáculos, 5 de abril de 1984, 2.

Sibila Camps, "La onda de hoy," Clarín, 23 de febrero de 1983, 25.

Sibila Camps, "Este Virus ya se lo habían pescado Los Beatles", Humor no. 74, enero de 1982, 62.

Roque de Pedro, "Rock y música andina en La Falda", Clarín, 31 de enero de 1983, 25. Roque de Pedro, "La sierra, con eco juvenil", Clarín, 8 de febrero de 1983, 38.

Jorge Dorio, "La insoportable levedad del psicobolche", El porteño no. 77, mayo de 1988.

Marcelo Figueras, "Esos chicos peligrosos", Humor no. 194, abril de 1987, 97-8.

Marcelo Figueras, "La decadencia del imperio psicobolche", Humor No. 195, abril de 1987, 70-72.

Claudio Gabis, "Carta a los músicos de los ochenta", Mutantia no. 2, agosto-septiembre de 1980, 14-16.

Miguel Grinberg, "Encuentro que me hiciste bien”, Humor no. 65, septiembre de 1981, 90-93

Gloria Guerrero, "Los jóvenes mil usos", Humor no. 112, septiembre de 1983, 58-9.

Gloria Guerrero, "Una extraña primavera", Humor no. 135, septiembre de 1984.

Gloria Guerrero, "Modern delirium: balance 1984", Humor no. 143, enero de 1985, 99-100.

Marcelo Helfgort, "El look 'tranqui' de los ochenta”, El porteño no. 77, mayo de 1988. 
Diego Lerer, "La postintelectualidad", Cerdos \& Peces no. 15, agosto de 1987.

Alfredo Leuco, "Semana crucial para el MOJUPO", Clarín, 11 de febrero de 1985, 9.

Miguel Angel Merellano, "El público en Obras", Humor no. 65, septiembre de 1981, 92.

Mona Moncalvillo, "León Gieco, el Dylan del subdesarrollo", Humor no. 79, abril de 1982, 78-80

Gabriel Pasquini, "Memorias de un psicobolche", El porteño no. 79, Julio de 1988, 61-3.

Claudia Pasquini, "Del monte al helecho" y "Dónde están los barbudos de entonces", El porteño no.

82, octubre de 1988.

Carlos Polimeni, "Al rock a hacer negocios", Clarín, 7 de marzo de 1985, 39.

Sandra Russo, "Subiendo línea: se viene el pasotismo", Humor no. 152, junio de 1985, 100.

Laura Sverdlik y Daniel Samailovich, "Ha nacido una nueva "tolerancia" en la universidad", Clarín Revista, 19 de junio de 1983, 4-5.

Enrique Symns, "Largo viaje al fin de la noche", El porteño no. 46, octubre de 1985, 20-4.

Alejandro Tarruela, "Silvio y Pablo, Daniel y Mario", Humor no. 126, abril de 1984.

Rodrigo Tarruela, "Derechos humanos sin folklore", Humor no. 224, Julio de 1988, 72.

Jorge Warley y Eduardo Berti, "Rock nacional: la batalla del milenio", El Porteño no. 65, mayo de 1987, 68-70.

\section{Prensa consultada}

Aquí y ahora la juventud (Federación Juvenil Comunista), 1981-1986.

Cerdos \& Peces, 1982-1990.

Clarín, 1980-1989.

El Porteño, 1982-1989.

El periodista de Buenos Aires, 1984-1989.

Humor, 1978-1989.

Luchar (Juventud Intransigente), 1982-1986.

Mutantia, 1979-1983.

Tiempo Argentino, 1982-1985. 